\title{
The Effect of Neonicotinoid Insecticide Thiacloprid on the Structure and Stability of DNA
}

\author{
V. VEREBOVÁ ${ }^{1}$, K. ŽELONKOVÁ ${ }^{1,2}$, B. HOLEČKOVÁ ${ }^{1}$, J. STANIČOVÁ ${ }^{1,3}$ \\ ${ }^{1}$ University of Veterinary Medicine and Pharmacy, Košice, Slovakia, ${ }^{2}$ Faculty of Science, \\ P. J. Šafárik University, Košice, Slovakia, ${ }^{3}$ Insitute of Biophysics and Informatics, First Faculty of \\ Medicine, Charles University, Prague, Czech Republic
}

Received June 13, 2019

Accepted September 25, 2019

\section{Summary}

The application of pesticides and chemical fertilizers constitutes a potential risk to human and animals due to the presence of their residues in the food. Thiacloprid belongs to a group of neonicotinoid insecticides. It shows a cytotoxic/cytostatic effect in human peripheral blood lymphocytes probably due to DNA damage. The use of thiacloprid is increasingly widespread worldwide, therefore is very important the assessment of its possible genotoxic and cytotoxic effects on a living organism. That is the reason why we studied the thiacloprid influence on the structure and stability of DNA in presented work. We have been studied the thiacloprid interaction with calf thymus DNA. Association constant was determined by fluorescence spectroscopy using equilibrium receptor-ligand binding analysis. The thermal denaturation of DNA was used to identify the mode of interaction. Viscosity changes were recorded to confirm/disconfirm the intercalation mode of interaction. Given the results, we can conclude that neonicotinoid pesticide thiacloprid destabilizes DNA. It changes the structure and stability of DNA through binding into the minor groove by hydrophobic or hydrogen interactions.

\section{Key words}

Thiacloprid • Interaction • DNA • Spectroscopy • Denaturation of DNA • Viscosity

\section{Corresponding author}

V. Verebová, Department of Chemistry, Biochemistry \& Biophysics, Institute of Biophysics, University of Veterinary Medicine and Pharmacy, Komenského 73, 04001 Košice, Slovak Republic. E-mail: valeria.verebova@uvlf.sk

\section{Introduction}

The introduction of modern inputs, such as pesticides and chemical fertilizers, has substantially increased agricultural productivity, quantity, quality and prolonging the lifetime of food and fodder plants. Pesticides have also revolutionized the fight against endemic diseases in developing countries. Unfortunately, there is a reverse side to this coin: these agents pose a potential risk to humans and animals due to presence of their residues in the food (Elbert et al. 2001).

Thiacloprid (TCL, Fig. 1) (3-(6-chloro-3pyridinylmethyl)-2-thiazolodinylidene)cyanamide) (CAS Number 111988-49-9) is an active component of the pesticide preparation Calypso 480SC.<smiles>N#CN=C1SCCN1Cc1ccc(Cl)nc1</smiles>

Fig. 1. Chemical structure of thiacloprid

TCL was developed for use on agricultural crops to control insects, especially aphids and little flies. It is protection product used on oilseed rape, fruit trees, vines, vegetables, potatoes and ornamental woods against mammalian and insect pests and flies (Elbert et al. 2001, Yu et al. 2007, Simon-Delso et al. 2015). TCL molecule 
is polar, white powder of TCL is soluble in water, organic solvents such as acetone, dichloromethane, dimethylsulfoxide and ethanol. Solubility is not affected by $\mathrm{pH}$ because TCL is stable in $\mathrm{pH}$ range 4-9. The low partition coefficient $(\log \mathrm{P}=1.26)$ indicates its poor fat solubility and low absorption and distribution in the body (USEPA 2003).

TCL belongs to a group of neonicotinoid insecticides, especially to the chloronicotinyl insecticides (Elbert et al. 2001). Neonicotinoid insecticides are systematic insecticides that bind to insect's nicotinic acetylcholine receptors (nAChR), causing abnormal excitation and leading to the death of insects through convulsive paralysis (Brown et al. 2006). Honey bees may also come into contact with these insecticides through the collection and feeding of contaminated nectar, pollen, and water. Many studies have found residues of neonicotinoid insecticides such as imidacloprid, thiamethoxam, and TCL in pollen, honey, and beeswax (Codling et al. 2016, Tosi et al. 2018). Several studies have investigated the effects of sublethal concentrations of TCL on honey bees, demonstrating negative impacts: on immunocompetence (Brandt et al. 2016), learning behaviour (Tison et al. 2017, De Lima et al. 2017), homing performance (Tison et al. 2016), and survival under pathological stress (Doublet et al. 2015). On the contrary, to some extent, TCL can be expeditiously detoxified by honey bees, and thus is classified safe for bees (Iwasa et al. 2004).

TCL is insecticide that enters the body through intimate contact or ingestion. Its mechanism of action is based on disruption of controlled synaptic transmission by irreversible binding to the nicotine acetylcholine receptor and attacks the nervous system of insects (Yu et al. 2007). Neonicotinoids have low affinity for nAChR of vertebrates at physiological $\mathrm{pH}$, because they are not protonated. As a result, they were supposed to show low acute and chronic toxicity in mammals, fish and birds, predominantly singers and poultry (Singla and Sandhu 2015). Nevertheless, it has been shown that TCL exhibits a relatively high level of acute toxicity for fish (Osterauer and Köhler 2008). After ingestion, TCL is rapidly absorbed, widely distributed inside the body, extensively metabolized and secreted in the urine. The target organ is the liver (Barden 2001).

Significant DNA damage was observed for Eisenia fetida, we can predict that TCL may have a harmful effect on earthworms (Feng et al. 2015). Some research groups reported that TCL showed a cytotoxic/cytostatic effect in human peripheral blood lymphocytes (Kocaman et al. 2014) and bovine peripheral lymphocytes (Galdiková et al. 2015) most probably due to the increased levels of DNA damage and that this effect resulted probably from the inhibition of DNA synthesis and cell proliferation. Because the use of TCL has become increasingly widespread throughout the world, the assessment of its possible genotoxic and cytotoxic effects on living organisms is very important. For this reason, we have aimed at TCL influence on the structure and stability of DNA. This interaction was studied by using fluorescence spectroscopy, absorption spectroscopy with Peltier module and viscosity measurements.

\section{Methods}

\section{Materials and solution preparation}

TCL and calf thymus DNA were obtained from Sigma-Aldrich (Germany). Stock solution of TCL $\left(5 \cdot 10^{-3} \mathrm{~mol} / \mathrm{l}\right)$ was prepared in $100 \%$ ethanol, which was purchased from Sigma-Aldrich (Germany). DNA $\left(3 \cdot 10^{-3} \mathrm{~mol} / \mathrm{l}\right)$ was dissolved in Tris-EDTA buffer (TE, $10 \mathrm{mmol} / 1$ Tris and $1 \mathrm{mmol} / 1$ EDTA), $\mathrm{pH}=7.4$ by stirring and held at $4{ }^{\circ} \mathrm{C}$. Ethidium bromide (EtBr) basic solution in water was purchased at concentration $1.3 \cdot 10^{-2} \mathrm{~mol} / 1$ from Sigma-Aldrich (Germany).

\section{UV-Vis studies}

UV-Vis measurements were made on absorption spectrophotometer Cary 60 UV-Vis Agilent Technologies using quartz cuvettes of $1-\mathrm{cm}$ path length at room temperature. UV-Vis titration were performed by constant concentration of TCL $\left(2 \cdot 10^{-5} \mathrm{~mol} / \mathrm{l}\right)$, concentration of DNA was changed in ratio $2 \cdot 10^{-5}-10^{-4} \mathrm{~mol} / 1$.

\section{Fluorescence measurements}

Fluorescence experiments were carried out at room temperature on spectrofluorimeter RF - 5301 PC Shimadzu. The bandwidth of excitation slit was set at $5 \mathrm{~nm}$ and emission slit at $3 \mathrm{~nm}$. The emission spectra at different DNA concentration $\left(3 \cdot 10^{-5}-4.8 \cdot 10^{-4} \mathrm{~mol} / \mathrm{l}\right)$ and fixed concentration of TCL $\left(3 \cdot 10^{-5} \mathrm{~mol} / \mathrm{l}\right)$ were recorded from 480 to $510 \mathrm{~nm}$ at room temperature and the excitation wavelength of $245 \mathrm{~nm}$ in Tris-EDTA buffer, $\mathrm{pH}$ 7.4. The fluorescence intensity was monitored at $493 \mathrm{~nm}$. The fluorescence quenching data were plotted according to the Stern-Volmer equation 
$\frac{F_{0}}{F}=1+K_{S V}[Q]$

where $F_{0}$ and $F$ are the fluorescence intensities in the absence and in the presence of the quencher $(Q)$ (Turro 1978). Then the binding parameters such as association constant $\left(K_{a}\right)$ and the number of binding sites $(n)$ were calculated according to Hill equation (Min et al. 2004, Tian et al. 2004)

$\frac{\log \left(F_{0}-F\right)}{F}=\log K_{a}+n \log [Q]$

where $F_{0}$ and $F$ are the fluorescence intensities of TCL in the absence and presence of quencher (DNA), $[Q]$ is the total DNA concentration. By the plot of $\log \left(F_{0}-F\right) / F$ versus $\log [Q]$, the number of binding sites $n$ and association constant can be obtained.

\section{Viscosity tests}

The viscosity of DNA solution was measured at $298.1 \pm 0.2 \mathrm{~K}$ using Ostwald viscometer and thermostatic water bath. DNA/EtBr, DNA/TCL solutions were prepared in the Tris-EDTA buffer $(\mathrm{pH}=7.4)$ as the solvent and the flow times of pure DNA $\left(5 \cdot 10^{-5} \mathrm{~mol} / \mathrm{l}\right)$ and their mixtures at various ratios $\left(2 \cdot 10^{-5}-\right.$ $1.3 \cdot 10^{-4} \mathrm{~mol} / \mathrm{l}$ ) through a capillary were read by use a digital stopwatch with an accuracy of $\pm 0.02 \mathrm{~s}$. To accurately evaluate the average relative viscosity of the samples, the mean values of ten replicate measurements were used. The data were presented as $\left(t / t_{0}\right)$ versus concentration of DNA and ligand (TCL or EtBr) ratio (Sahoo et al. 2008).

\section{DNA melting studies}

Thermal stability of DNA was recorded on absorption spectrophotometer Cary $60 \mathrm{UV}-\mathrm{V}$ is Agilent Technologies connected with Peltier module. The melting temperatures $\left(T_{m}\right)$ of pure DNA $\left(3 \cdot 10^{-5} \mathrm{~mol} / \mathrm{l}\right)$ and DNA/TCL complexes $(1 / 1,1 / 2$ and $1 / 3)$ were measured by monitoring the $260 \mathrm{~nm}$ absorption intensities of samples at a variety of temperatures. Concentration of TCL were changed from $3 \cdot 10^{-5}$ to $9 \cdot 10^{-5} \mathrm{~mol} / \mathrm{l}$. Temperature was increased with step $5{ }^{\circ} \mathrm{C}$ by this experimental arrangement. Temperature range of measurement was $25-95{ }^{\circ} \mathrm{C}$. The samples were filtrated on MillexGV $(0.22 \mu \mathrm{m})$ before measurement. Melting curves were fitted by Van't Hoff equation (Pace 1990)

$$
A=A_{\min }+\frac{A_{\max }-A_{\min }}{1+e^{\left[\frac{\Delta H}{R} x\left(\frac{1}{T^{-}}-\frac{1}{T_{m}}\right)\right]}}
$$

where $A$ is absorbance, $A_{\min }, A_{\max }$ are minimal and maximal measured absorbance, respectively, $H$ is enthalpy of transition, $R$ is gas constant, $T, T_{m}$ are actual temperature and melting temperature.

All spectra and graphs were evaluated in Origin 6.0 and 8.0 and Grafit programs.

\section{Results}

\section{UV-Vis studies}

Fig. 2 presents the UV-Vis absorption spectra. The absorption band of TCL was observed in the UV region with maximum at approximately $245 \mathrm{~nm}$.

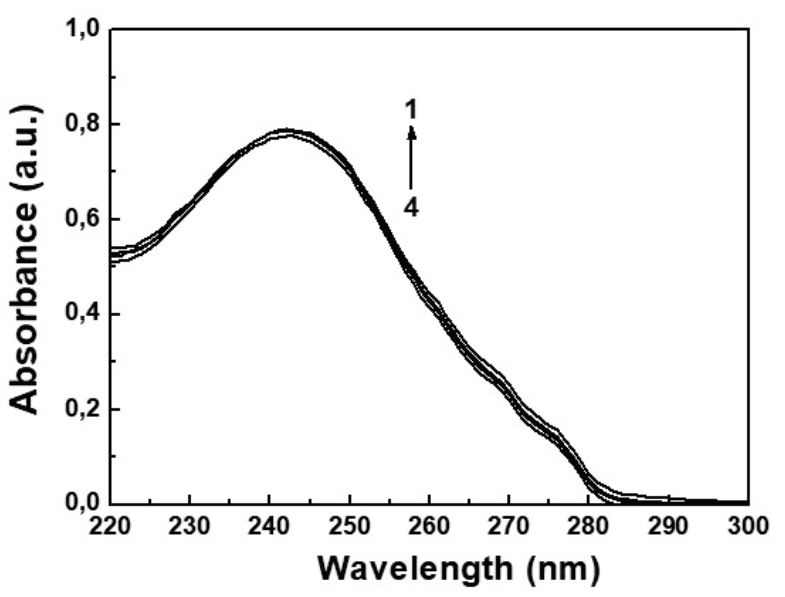

Fig. 2. Absorption spectra of TCL $\left(2 \cdot 10^{-5} \mathrm{~mol} / \mathrm{l}\right)$ after addition of DNA $\left(2 \cdot 10^{-5}-10^{-4} \mathrm{~mol} / \mathrm{l}\right)$ in Tris-EDTA buffer $\mathrm{pH} 7.4$, lines $1-4$ : $\mathrm{C}(\mathrm{TCL} / \mathrm{DNA})=1 / 0,1 / 1,1 / 21 / 5$, respectively. The arrow indicates the absorbance changes with increasing of DNA concentration.

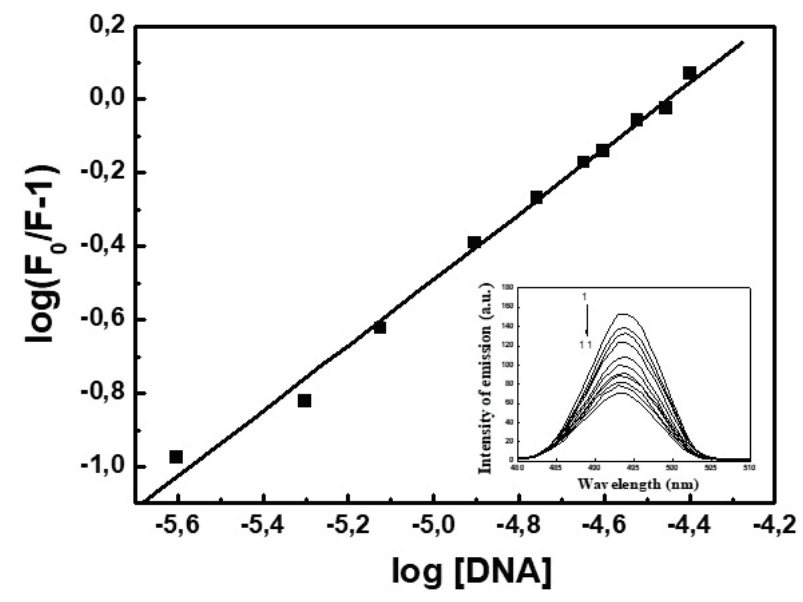

Fig. 3. Hill plot of DNA quenching effect on TCL fluorescence. Insert: Fluorescence spectra of TCL in the absence and presence of DNA; $c(T C L)=3 \cdot 10^{-5} \mathrm{~mol} / \mathrm{l}$ and $\mathrm{C}(\mathrm{DNA})=3 \cdot 10^{-5}-$ $4.8 \cdot 10^{-4} \mathrm{~mol} / \mathrm{l}$, lines $1-11: \mathrm{c}(\mathrm{TCL} / \mathrm{DNA})=1 / 0,1 / 1,1 / 2,1 / 3$, $1 / 5,1 / 7,1 / 9,1 / 10,1 / 12,1 / 14,1 / 16$, respectively. $\lambda_{\mathrm{exc}}=245 \mathrm{~nm}$, $\lambda_{\mathrm{em}}=480-510 \mathrm{~nm}$ 
We observed a very slight increase in the absorbance intensity with growing of DNA concentration.

\section{Fluorescence measurements}

For this study, the fluorescence behaviour of TCL has been monitored. Fig. 3 (insert) displays the fluorescence emission spectra of TCL in presence of increasing concentration of DNA. The emission maximum of TCL at $493 \mathrm{~nm}$ gradually decreased. The quenching of fluorescence intensity of TCL on addition of DNA is indicative of an interaction. A quantitative estimation of the quenching in terms of the fluorescencequenching constant was analysed using Stern-Volmer equation (1). The representative plot of $F_{0} / F$ versus [Q] (not shown) of the present system shows a linear growth of the curve with addition of DNA. The quenching constant $\left(K_{S V}\right)$ was found to be $2.8 \cdot 10^{4} \mathrm{l} / \mathrm{mol}$ and correlation coefficient for the $K_{S V}$ value was $\mathrm{R}=0.998$.

Subsequently, the values of $K_{a}$ and number of binding sites $n$ were determined by linear regression of $\log \left(F_{0} / F-1\right)$ versus $\log [Q]$. This dependence represents Hill plot (Fig. 3) expressed by equation (2). The calculated value of association constant $K_{a}$ was $9.3 \cdot 10^{3} \mathrm{l} / \mathrm{mol}$, correlation coefficient for the $K_{a}$ value was $\mathrm{R}=0.996$ and number of binding sites was set at approximately $1(n=0.89)$. Results obtained from fluorescence measurements are summarized in Table 1.

\section{Viscosity tests}

Further information on the nature of the interaction can be obtained through hydrodynamic studies. This includes viscometric measurements.

We have been measured the variation in relative viscosity of DNA/EtBr and DNA/TCL complexes. In the viscosity curve in Fig. 4, we detected a significant increase in viscosity for $\mathrm{EtBr}$ and not considerably change upon adding TCL into DNA.

\section{DNA melting studies}

When DNA solutions are exposed to extremes of $\mathrm{pH}$ or heat, the double helical structure of DNA undergoes a transition into a random single-stranded form at the melting temperature. The melting temperature can be also altered by the interaction of DNA with small molecules (Ma et al. 2012). We have proved our results by denaturation of pure DNA and DNA/TCL complexes in ratios $1 / 1,1 / 2,1 / 3$ by absorption spectroscopy connected with a Peltier module. Melting curves that can be seen in Fig. 5 show a destabilizing effect of the TCL on DNA. They were fitted using Van't Hoff equation (3) to obtain main thermodynamic characteristics $\left(T_{m}, T, \Delta T\right.$, $\Delta H)$.

Melting temperature $T_{m}$ is shifted about $2.6{ }^{\circ} \mathrm{C}$ from pure DNA $\left(64.5^{\circ} \mathrm{C}\right)$ to the complex DNA/TCL in $1 / 2$ concentration ratio $\left(61.9{ }^{\circ} \mathrm{C}\right)$. Also Van't Hoff enthalpy $\Delta H$ is decreasing from $413.6 \mathrm{~kJ} / \mathrm{mol}$ (pure DNA) to $390.6 \mathrm{~kJ} / \mathrm{mol}$ (DNA/TCL $=1 / 2)$ (Table 2). Measurements for complex DNA/TCL in 1/3 (Table 2) shows a two-phase character.

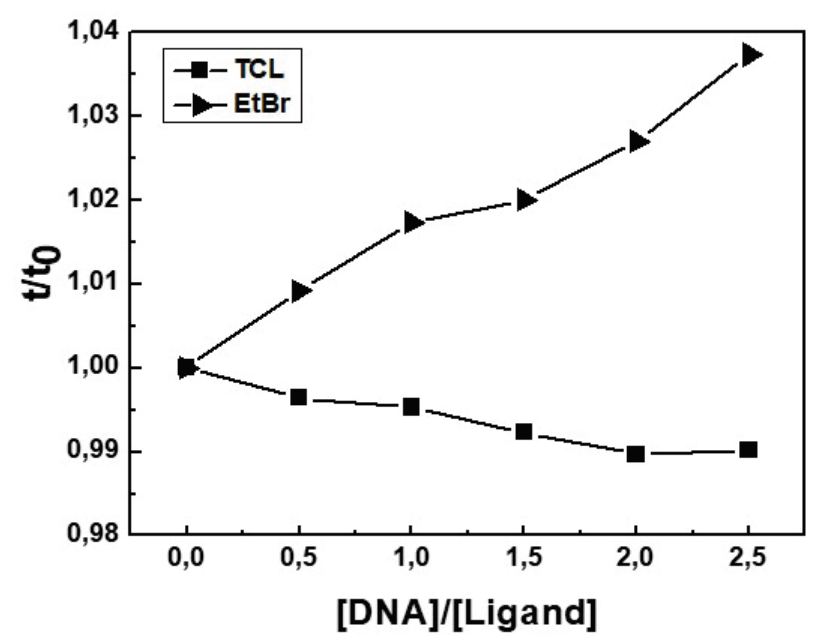

Fig. 4. Plot of flow time $t / t_{0}$ versus $[D N A] /[$ ligand], where $t$ is the flow time of the complex $\mathrm{DNA}$ /ligand ( $\mathrm{TCL}$ or EtBr, respectively) and $t_{0}$ is the flow time of DNA. c (DNA) $=5 \cdot 10^{-5} \mathrm{~mol} / \mathrm{l}, \mathrm{c}$ (ligand) $=2 \cdot 10^{-5}-1.3 \cdot 10^{-4} \mathrm{~mol} / \mathrm{l} ;[D N A] /[$ ligand $]=1 / 0,1 / 0.5,1 / 1,1 / 2$, $1 / 2.5$

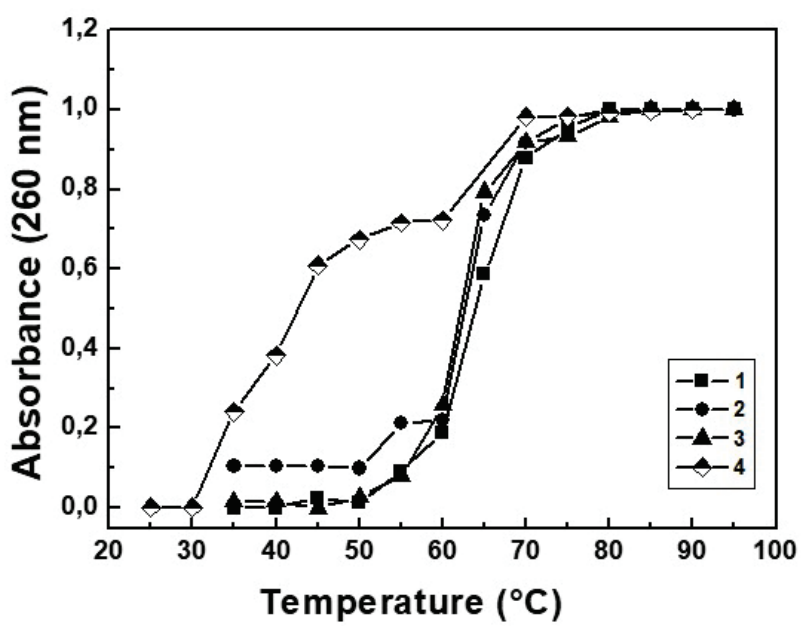

Fig. 5. Normalized melting curves of pure DNA (1) and complexes TCL/DNA in ratio 1/1 (2), 1/2 (3), 1/3 (4). $c($ DNA $)=$ $3 \cdot 10^{-5} \mathrm{~mol} / \mathrm{l}$ and $\mathrm{c}(\mathrm{TCL})=3 \cdot 10^{-5}-9 \cdot 10^{-5} \mathrm{~mol} / \mathrm{l}$ 
Table 1. Quenching constant $\left(K_{S V}\right)$, association constant $\left(K_{a}\right)$ and number of binding sites $(n)$ for the interaction of TCL with DNA at room temperature

\begin{tabular}{cccccc}
\hline $\mathbf{T}(\mathbf{K})$ & $\mathbf{K}_{\text {SV }}(\mathbf{l} / \mathbf{m o l})$ & $\mathbf{R}^{\mathbf{a}}$ & $\mathbf{K}_{\mathbf{a}}(\mathbf{l} / \mathbf{m o l})$ & $\mathbf{R}^{\mathbf{b}}$ & $\mathbf{n}$ \\
\hline 298 & $2.8 \cdot 104 \pm 0.0467$ & 0.998 & $9.3 \cdot 103 \pm 0.1268$ & 0.996 & $0.89 \pm 0.0261$ \\
\hline
\end{tabular}

${ }^{a}$ Correlation coefficient for the $K_{S V}$ value, ${ }^{\mathrm{b}}$ Correlation coefficient for the $K_{a}$ value

Table 2. Thermodynamic characteristics determined from the melting curves of pure DNA and complexes DNA/TCL

\begin{tabular}{|c|c|c|c|c|c|c|c|c|c|c|}
\hline & \multicolumn{5}{|c|}{$1^{\text {st }}$ phase } & \multicolumn{5}{|c|}{$2^{\text {nd }}$ phase } \\
\hline & $\begin{array}{l}\mathbf{T}_{\mathbf{m}} \\
\left({ }^{\circ} \mathbf{C}\right)\end{array}$ & $\begin{array}{c}\mathrm{T}_{1} \\
\left({ }^{\circ} \mathrm{C}\right)\end{array}$ & $\begin{array}{c}\mathbf{T}_{2} \\
\left({ }^{\circ} \mathbf{C}\right)\end{array}$ & $\begin{array}{c}\Delta \mathrm{T} \\
\left({ }^{\circ} \mathrm{C}\right)\end{array}$ & $\begin{array}{c}\Delta \mathbf{H} \\
(\mathrm{kJ} / \mathrm{mol})\end{array}$ & $\begin{array}{l}\mathbf{T}_{\mathrm{m}} \\
\left({ }^{\circ} \mathrm{C}\right)\end{array}$ & $\begin{array}{c}\mathrm{T}_{1} \\
\left({ }^{\circ} \mathrm{C}\right)\end{array}$ & $\begin{array}{c}\mathrm{T}_{2} \\
\left({ }^{\circ} \mathbf{C}\right)\end{array}$ & $\begin{array}{c}\Delta \mathrm{T} \\
\left({ }^{\circ} \mathrm{C}\right)\end{array}$ & $\begin{array}{c}\Delta \mathrm{H} \\
(\mathrm{kJ} / \mathrm{mol})\end{array}$ \\
\hline$D N A$ & 64.5 & 56.2 & 73.6 & 17.4 & 413.6 & & & & & \\
\hline $\begin{array}{l}D N A / T C L \\
1 / 1\end{array}$ & 63.4 & 56.2 & 71.7 & 15.5 & 396.1 & & & & & \\
\hline $\begin{array}{l}D N A / T C L \\
1 / 2\end{array}$ & 61.9 & 56.4 & 68.0 & 11.6 & 390.6 & & & & & \\
\hline $\begin{array}{l}D N A / T C L \\
1 / 3\end{array}$ & $36.6^{\mathrm{AT}}$ & 25.2 & 50.1 & 24.9 & 200.4 & $63.2^{\mathrm{GC}}$ & 58.9 & 69.9 & 11 & 315.4 \\
\hline
\end{tabular}

${ }^{\text {AT }} T_{m}$ for AT pairs, ${ }^{\text {GC }} T_{m}$ for GC pairs

\section{Discussion}

Small molecules, such as pesticides, bind to the double helix of DNA by two dominant modes, referred to as groove binding and intercalation. Groove binding involves docking the thin ribbon-like molecules in the DNA minor groove, in close proximity to the sugarphosphate backbone. In contrast, intercalation of small molecules into the helix involves the insertion of the drug - usually a planar aromatic cation - into the base stack of the helix (Kumar et al. 1993). When a molecule is intercalated between base pairs of nucleic acids, usually a marked substantial hypochromicity of the absorption maximum is observed (Sahoo et al. 2008). We recorded although slight but still an increasing TCL absorption spectra when DNA was added. The method of absorption spectroscopy is a bulk method and the changes in our experimental absorption spectra were very weak. It was unclear to conclude if TCL interacts with DNA. Therefore, we have used the fluorescence spectroscopy to study the effect of TCL on DNA molecule.

Fluorescence spectroscopy can be used to clarify the binding characteristics of the chromophore with other molecules (Modukuru et al. 2005). An enhanced fluorescence is believed to be one of the criteria for intercalative binding (Sehlstedt et al. 1994, Zupan et al.
2004). The classical intercalator EtBr is known to exhibit significant fluorescence enhancement on binding to double-stranded DNA (dsDNA) (Bresloff and Crothers 1981, Olmsted and Kearns 1977). On the other hand, the interaction between agent naproxen and dsDNA in a groove-binding mode causes a strong fluorescence quenching (Ye et al. 2005). Thus it is apparent that further experiments were required to determine the mode of binding since no conclusion may be drawn based on fluorescence spectral behaviour alone.

Comparing the TCL association constant with typical DNA intercalators such as $\operatorname{EtBr}\left(K_{a}=\right.$ $\left.1.4 \cdot 10^{6} \mathrm{l} / \mathrm{mol}\right)$ (Chen et al. 2012) or danthron $\left(K_{a}=\right.$ $7.2 \cdot 10^{6} \mathrm{l} / \mathrm{mol}$ ) (Gholivand et al. 2011) and drugs binding by weak electrostatic forces to the surface of DNA as they are naringin $\left(K_{a}=3.1 \cdot 10^{3} \mathrm{l} / \mathrm{mol}\right)$ (Jourdan et al. $1985)$ and vincristine $\left(\left(K_{a}=1.0 \cdot 10^{3} \mathrm{l} / \mathrm{mol}\right)\right.$ (Tyagi et al. 2010) we can claim that association constant of our pesticide does not point an intercalation mode and binding via electrostatic forces as well. We can suppose that TCL binds to the DNA groove, since the value of the association constant corresponds to this type of binding (Gholivand et al. 2011).

The hydrodynamic method, which is rather sensitive to variations in the length of the DNA molecule, can be the most effective method for studying the DNA- 
complex binding modes without requiring X-ray crystallography or structural NMR data (Li et al. 2006). In classical intercalators the length of DNA helix is increased, given that base pairs are distanced to accommodate the interacting species. This increases the viscosity (Kashanian et al. 2010). On the other hand, the partial and non-classical intercalations may bend the DNA helix, and hence lower its length and consequently the viscosity. Further, the molecular binding in the DNA grooves causes less marked positive or negative changes in the viscosity of the solution (Kelly et al. 1985, Sahoo et al. 2008). Result of viscometric measurement of DNA/TCL complexes is the stagnancy/slight decrease in viscosity. We recorded a significant change in viscosity behavior as a result of TCL addition to the DNA solution. Viscometric measurements confirm the observation we have given from previous measurements and finally we can claim that TCL does not interact with DNA through intercalation mode but by binding into the groove.

Usually, classic intercalation of small molecules into the double helix causes stabilization of base stacking and leads to a significant increase of $T_{m}$ (approximately $5-8{ }^{\circ} \mathrm{C}$ ), whereas non-intercalation (e.g. groove or electrostatic) binding induces no obvious increase in $T_{m}$ (Sun et al. 2011). From our measurements it is obvious that melting temperature increment was smaller than $5^{\circ} \mathrm{C}$ $\left(2.6{ }^{\circ} \mathrm{C}\right)$, and therefore it can be deduced that TCL interacted with DNA via non-classic intercalation. This interaction can be realized via groove or electrostatic binding mode. Decrease of Van't Hoff enthalpy means that lower energy is needed for denaturation of $50 \%$ base pairs of DNA in the complex with TCL. The changes in all thermodynamic parameters lead us to a claim that
TCL destabilizes the DNA molecule. This destabilization is associated with the groove binding interaction mode (Bi et al. 2008). In our experiments the melting curve of the complex DNA/TCL in $1 / 3$ indicates a two-phase character with an expression destabilization of AT regions in DNA. It is generally supposed that small molecules which consist of at least two aromatic rings coupled by non-rigid bond enabling their torsional flexibility, like pesticide TCL bind preferentially into the minor groove of DNA, especially to regions which are rich in AT-base pairs (Lavery and Pullman 1981, Ihmels et al. 2005).

In conclusion, the association constant value of TCL leads us to assume that this neonicotinoid pesticide does not bind into the DNA structure by an intercalative mode of interaction. TCL influence on length and denaturation of the DNA macromolecule points to the groove binding mode of interaction. Incorporation of this insecticide occurs probably into DNA minor groove by hydrophobic or hydrogen interactions. The fact that the intercalative mode of interaction represents in higher value of association constant, increase of DNA length, slight decrease in viscosity and thermal stabilization of DNA due to ligand binding (Bi et al. 2008) proves our conclusions.

\section{Conflict of Interest}

There is no conflict of interest.

\section{Acknowledgements}

This work was supported by the research grant from Slovak agency VEGA No. 1/0242/19 and KEGA No. 012 UVLF-4/2018.

\section{References}

BARDEN G: Evaluation of the new active thiacloprid in the new product Calypso 480 SC insecticide. In: National Registration Authority for Agricultural and Veterinary Chemicals. Kingston, Australia, 2001, pp 240.

BI S, ZHANG H, QIAO C, SUN Y, LIU C: Studies of interaction of emodin and DNA in the presence of ethidium bromide by spectroscopic method. Spectrochim Acta A Mol Biomol Spectrosc 69: 123-129, 2008.

BRANDT A, GORENFLO A, SIEDE R, MEIXNER M, BÜCHLER R: The neonicotinoids thiacloprid, imidacloprid, and clothianidin affect the immunocompetence of honey bees (Apis mellifera L.). J Insect Physiol 86: 40-47, 2016.

BRESLOFF JL, CROTHERS DM: Equilibrium studies of ethidium-polynucleotide interactions. Biochemistry 20: 3547-3553, 1981.

BROWN LA, IHARA M, BUCKINGHAM SD, MATSUDA K, SATTELLE DB: Neonicotinoid insecticides display partial and super agonist actions on native insect nicotinic acetylcholine receptors. $J$ Neurochem 99: 608-615, 2006. 
CHEN ZG, ZHANG GM, CHEN ZX, GAO WH: A resonance light-scattering off-on system for studies of the selective interaction between adriamycin and DNA. Anal Bioanal Chem 402: 2163-2171, 2012.

CODLING G, AL NAGGAR NY, GIESY JP, ROBERTSON AJ: Concentrations of neonicotinoid insecticides in honey, pollen and honeybees (Apis mellifera L.) in central Saskatchewan, Canada. Chemosphere 144: 2321-2328, 2016.

DE LIMA E SILVA C, BRENNAN N, BROUWER JM, COMMANDEUR D, VERWEIJ RA, VAN GESTEL GAM: Comparative toxicity of imidacloprid and thiacloprid to different species of soil invertebrates. Ecotoxicology 26: 555-564, 2017.

DOUBLET V, LABARUSSIAS M, DE MIRANDA JR, MORITZ RF, PAXTON RJ: Bees under stress: sublethal doses of a neonicotinoid pesticide and pathogens interact to elevate honey bee mortality across the life cycle. Environ Microbiol 17: 969-983, 2015.

ELBERT A, BUCHHOLZ A, EBBINGHAUS-KINTSCHER U, ERDELEN C, NAUEN R, SCHNORBACH HJ: The biological profile of thiacloprid-A new chloronicotinyl insecticide. Pflanzenschutz-Nachr Bayer 54: 185-208, 2001.

FENG L, ZHANG L, ZHANG Y, ZHANG P, JIANG H: Inhibition and recovery of biomarkers of earthworm Eisenia fetida after exposure to thiacloprid. Environ Sci Pollut Res Int 22: 9475-9482, 2015.

GALDÍKOVÁ M, ŠIVIKOVÁ K, HOLEČKOVÁ B, DIANOVSKÝ J, DRÁŽOVSKÁ M, SCHWARZBACHEROVÁ $\mathrm{V}$ : The effect of thiacloprid formulation on DNA/chromosome damage and changes in GST activity in bovine peripheral lymphocytes. J Environ Sci Health B 50: 698-707, 2015.

GHOLIVAND MB, KASHANIAN S, PEYMAN H, ROSHANFEKR H: DNA-bindind study of anthraquinone derivatives using chemometrics methods. Eur J Med Chem 46: 2630-2638, 2011.

IHMELS H, FAULHABER K, VEDALDI D, DALL' ACQUA F, VIOLA G: Intercalation of organic dye molecules into double-stranded DNA. Part 2: the annelated quinolizinium ion as a structural motif in DNA intercalators. Photochem Photobiol 81: 1107-1115, 2005.

IWASA T, MOTOYAMA N, AMBROSE JT, ROE RM: Mechanism for the differential toxicity of neonicotinoid insecticides in the honey bee, Apis mellifera. Crop Prot 23: 371-378, 2004.

JOURDAN PS, MCINTOSH CA, MANSELL RL: Naringin levels in citrus tissues. II. Quantitative distribution of naringin in Citrus paradise MacFed. Plant Physiol 77: 903-908, 1985.

KASHANIAN S, KHODAEI MM, PAKRAVAN P: Spectroscopic studies on the interaction of isatin with calf thymus DNA. DNA Cell Biol 29: 639-646, 2010.

KELLY JM, TOSSI AB, MCCONNELL DJ, OHUIGIN C: A study of the interactions of some polypyridylruthenium (ii) complexes with DNA using fluorescence spectroscopy, topoisomerisation and thermal denaturation. Nucleic Acids Research 13: 6017-6034, 1985.

KOCAMAN AY, RENCÜZOGULLARI E, TOPAKTAS M: In vitro investigation of the genotoxic and cytotoxic effects of thiacloprid in cultured human peripheral blood lymphocytes. Environ Toxicol 29: 631-641, 2014.

KUMAR CV, TURNER RS, ASUNCION EH: Groove binding of a styrylcyanine dye to the DNA double helix: the salt effect. J Photochem Photobiol A: Chem 74: 231-238, 1993.

LAVERY R, PULLMAN B: Molecular electrostatic potential on the surface envelopes of macromolecules: B-DNA. Int J Quantum Chem 20: 259-272, 1981.

LI FH, ZHAO GH, WU HX, LIN H, WU XX, ZHU SR, LIN HK: Synthesis, characterization and biological activity of lanthanum (iii) complexes containing 2-methyl-1, 10-phenanthroline units bridged by aliphatic diamines. J Inorg Biochem 100: 36-43, 2006.

MA YD, ZHANG GW, PAN JH: Spectroscopic studies of DNA interaction with food colorant indigo carmine with the use of ethidium bromide as a fluorescence probe. J Agric Food Chem 60: 10867-10875, 2012.

MIN J, MENG-XIA X, DONG Z, YUAN L, XIAO-YU L, XING C: Spectroscopic studies on the interaction of cinnamic acid and its hydroxyl derivatives with human serum albumin. J Mol Struct 692: 71-80, 2004.

MODUKURU NK, SNOW KJ, PERRIN BS, THOTA J JR, KUMAR CV: Contributions of a long side chain to the binding affinity of an anthracene derivative to DNA. J Phys Chem B 109: 11810-11818, 2005.

OLMSTED J III, KEARNS DR: Mechanism of ethidium bromide fluorescence enhancement on binding to nucleic acids. Biochemistry 16: 3647-3654, 1977. 
OSTERAUER R, KÖHLER HR: Temperature-dependent effects of the pesticides thiacloprid and diazinon on the embryonic development of zebrafish (Danio rerio). Aquat Toxicol 86: 485-494, 2008.

PACE CN: Measuring and increasing protein stability. Trends Biotechnol 8: 93-98, 1990.

SAHOO BK, GHOSH KS, BERA R, DASGUPTA S: Studies on the interaction of diacetylcurcumin with calf thymusDNA. Chem Phys 351: 163-169, 2008.

SEHLSTEDT V, KIM SK, CARTER P, GOODISMAN J, VOLLANO JF, NORDEN B, DABROWIAK JC: Interaction of cationic porphyrins with DNA. Biochemistry 33: 417-426, 1994.

SIMON-DELSO N, AMARAL-ROGERS V, BELZUNCES LP, BONMATIN JM, CHAGNON M, DOWNS C, FURLAN L, GIBBONS DW, GIORIO C, GIROLAMI V: Systemic insecticides (neonicotinoids and fpronil): trends, uses, mode of action and metabolites. Environ Sci Pollut Res 22: 5-34, 2015.

SINGLA S, SANDHU HS: Alterations in haematological profile of experimentally induced subchromic thiacloprid toxicosis in gallus domesticus. Toxicol Int 22: 147-151, 2015.

SUN YT, ZHANG HQ, BI SY, ZHOU XF, WANG L, YAN YS: Studies on the arctilin and its interaction with DNA by spectral methods. J Lumin 131: 2299-2306, 2011.

TIAN J, LIU J, HE W, HU Z, YAO X, CHEN X: Probing the binding of scutellarin to human serum albumin by circular dichroism, fluorescence spectroscopy, FTIR, and molecular modeling method. Biomacromolecules $\mathbf{5}$ : 1956-1961, 2004.

TISON L, HAHN ML, HOLTZ S, ROSSNER A, GREGGERS U, BISCHOFF G, MENZEL R: Honeybees' behaviour is impaired by chronic exposure to the neonicotinoid thiacloprid in the field. Environ Sci Technol 50: 7218-7227, 2016.

TISON L, HOLTZ S, ADEOYE A, KALKAN Ö, IRMISCH NS, LEHMANN N, MENZEL R: Effects of sublethal doses of thiacloprid and its formulation Calypso (R) on the learning and memory performance of honey bees. J Exp Biol 220: 3695-3705, 2017.

TOSI S, COSTA C, VESCO U, QUAGLIA G, GUIDO G: A 3-year survey of Italian honey bee-collected pollen reveals widespread contamination by agricultural pesticides. Sci Total Environ 615: 208-218, 2018.

TURRO NJ: Modern molecular photochemistry. In: Benjamin-Cummings. Menlo Park, CA, 1978, pp 305.

TYAGI G, JANGIR DK, SINGH P, MEHROTRA R: DNA interaction studies of an anticancer plant alkaloid, vincristine, using Fourier transform infrared spectroscopy. DNA Cell Biol 29: 693-699, 2010.

USEPA/OPPTS: Pesticide Fact Sheet. Thiacloprid. Environmental Protection Agency Washington, DC, 2003. Available from as of October 27, 2004: http://www.epa.gov/opprd001/factsheets/thiacloprid.pdf

YE BF, ZHANG ZJ, JU HX: Fluorescence study on the interaction between naproxen and yeast DNA. Chin J Chem 23: $58-62,2005$.

YU YL, WU JL, STAHLER M, PESTEMER W: Residual dynamics of thiacloprid in medical herbs marjoram, thyme, and camomile in soil. $J$ Environ Sci 19: 205-209, 2007.

ZUPAN K, HERENYI L, TOTH K, MAJER Z, CSIK G: Binding of cationic porphyrin to isolated and encapsidated viral DNA analysed by comprehensive spectroscopic methods. Biochemistry 43: 9151-9159, 2004. 